dictably, the growth in number of private HEIs will slow down, as more stringent quality requirements are enforced.

\section{University Branch Campuses in Kenya}

\section{ISHMAEL I. MUNENE}

Ishmael I. Munene is associate professor in the Educational Leadership Department, Northern Arizona University, US. E-mail: Ishmael. Munene@nau.edu.

$\mathrm{O}$ n January I9, 2016, in an unprecedented demonstration of clout, the Kenya Commission for University Education (CUE) ordered Kisii University, a state institution, to close Io of its I3 branch campuses, and relocate the I5,000 students affected to the main campus. This move brings to 20 the number of campuses ordered closed by the authorities. These actions are the culmination of concerted efforts by regulatory authorities to recalibrate university growth, from an array of low-quality, demand-absorbing campuses back to a traditional system of specialized, highquality campuses. It is also a response to stakeholders concerns over the decline in quality, as a result of the commercialization of the university sector. The existence of campus networks in major universities has a long history. However, its surge in Kenya in the last decade has been explosive.

Kenya's university landscape, especially the public sector, is now a collection of campuses strewn all over the country and competing for the same student clientele. Whereas a decade ago the campus model was regarded as the panacea to the challenges of university demand and revenue diversification in the neo-liberal era, the model is now viewed with suspicion. It epitomizes the worst tendencies of university growth catalyzed by both social demand and commercialization, in the context of weak regulatory authorities.

\section{IMPETUS FOR CAMPUS GROWTH}

Given the rapid growth of branch campuses in the public sector in the last decade, it is important to highlight budgetary constraints, access, and equity as the key factors motivating this development.

Of the main drivers of the multicampus systems in Kenya's state universities, none ranks higher than institutional revenue diversification. Acute state revenue constraints beginning in the late I990s, and the subsequent reduction of state funding of universities, have forced the institutions to seek additional revenues from the marketplace. The universities have adopted a low-cost revenue enhancement model around inexpensive branch campuses targeting selfsponsored students (high school graduates without government scholarships) and working adults. Most of these campuses are in small rural towns and offer easy-to-mount courses in humanities, education, and business, taught by poorly qualitied part-time faculty. The target students pay market-based tuition charges and fees, which contributes a large percentage of the universities' additional revenues. Since the campuses are inexpensive to establish and generate high financial returns, universities have a strong incentive to establish numerous branch campuses.

Though the number of universities in Kenya has grown from one public university to the current 43 accredited universities ( 33 public and Io private), the challenge of access remains, as the current enrollment of around 324,000 represents only 30 percent of the eligible population. The number of students graduating from high school far exceeds the available number of university places, while the number of working adults seeking university education grows. University authorities have viewed leasing facilities for the establishment of campuses as the most practical approach to expand access in the context of reduced state subventions, for construction of capital facilities at the main campuses.

Most public and private universities are located in major metropolitan areas and in rich agricultural regions of central and western Kenya, leaving large swaths of the country without universities. These disadvantaged areas also experience greater levels of poverty. National educational authorities have, therefore, viewed low-cost campuses in marginal areas as a solution to the twin challenges of equity of access and economic disadvantage. It is not surprising that many campuses have been established in the low-income coastal, eastern, and north-eastern regions of the country.

These social goals have been the reason why regulatory authorities have overlooked the pitfalls of a university system characterized by low-quality branch campuses. The campuses have been a double-edged sword, providing access and equity while simultaneously compromising quality and equity.

\section{Quality and Equity Challenge}

Questionable educational quality in branch campuses is the utmost concern expressed by stakeholders. From academic facilities to academic staff, many branch campuses offer a grim contrast to the main campuses of the universities. In most rural urban centers, branch campuses share buildings with business establishments like pubs, restaurants, supermarkets, brothels, and bus terminals. They lack libraries, internet facilities, student services, as well as recreational 
amenities. Other than a full-time campus director, the academic staff consists of adjunct faculty who hold master's degrees, sometimes of dubious credibility. Rarely are academic conferences, seminars, and research symposiums hosted in the campuses. Not only does this environment impede excellent teaching and learning, but it also perpetuates teaching-research divorce, even in premier national universities. Surprisingly, most of these campuses purport to offer research-oriented master's degrees.

\section{It epitomizes the worst tendencies of university growth catalyzed by both so- cial demand and commercialization, in the context of weak regulatory authori- ties.}

All branch campuses exhibit a common characteristic: a restrictive academic narrowness. Commercially oriented programs dominate academic offerings, with business studies, economics, and project management as the most popular. Other dominant fields include education, humanities, and social sciences. Engineering, the natural sciences, and the medical sciences are rarely offered at the branch campuses. Because branch campuses are peripheral appendages created to generate revenue and absorb demand, the central university administrators are reluctant to offer programs that could evolve into potential competitors to the main campuses for government-sponsored student numbers and state financial resources.

In as much as campuses have enhanced access, they also reveal the dark side of the intersection between social class membership and university access in Kenya. Rural campuses largely attract self-sponsored students who, as a result of their lower socioeconomic status, could not perform well enough in high school examinations to secure competitive government scholarships. With students from more privileged backgrounds taking the larger share of government scholarships and, therefore, places in the wellresourced main university campuses, the branch model of university development has contributed to the bifurcation of state universities: students from more privileged backgrounds dominate the well-resourced main campuses, while those from underprivileged classes are overrepresented in branch campuses. Branch campuses, therefore, contribute to the failure to address issues of substantive equity in higher education.

\section{Recalibrating the Branch Campus Model}

The Kenyan multibranch campus model of higher education is there to stay, granted its benefits in the commercialized higher education climate. While ensuring that campus resources meet minimum acceptable standards, as CUE is currently doing, is an appropriate short-term measure, the long-term solution lies in reconfiguring the university campus system. The state needs to support the development of branch campuses that not only provide access, but also address the socioeconomic and cultural problems in the regions where they are located. This will promote the hiring of qualified faculty, diverse academic programs congruent with local challenges, engagement in research and scholarship, and the mentoring of graduate students. Granting such campuses administrative autonomy in certain areas of finance and academic programing will enhance decisionmaking on critical issues. Elements of this model of branch organization are already evident in the organizational model of the University of Nairobi colleges.

\section{Chilean Universities: Not So Tuition-free After All}

\section{Ariane de Gayardon and Andrés Bernasconi}

Ariane de Gayardon is a PhD candidate in higher education at the Boston College Lynch School of Education as well as a graduate assistant at the Center for International Higher Education (CIHE), US. E-mail: ariane.degayardon@bc.edu. Andrés Bernasconi is associate professor and vice-dean at the School of Education of the Pontificia Universidad Católica de Chile, Santiago, Chile.E-mail: abernasconi@uc.cl.

The dictatorship of General Pinochet in Chile (19731 I990) expanded private higher education and introduced tuition fees in the higher education public sector. Three decades later, Chile is the OECD country with the smallest share of public expenditure in the overall tertiary education spending. It also has the second highest level of tuition fees after US private universities, when adjusted to the per capita gross national product.

In 20II, Chilean students demonstrated massively against the marketization of the higher education system, making free higher education for all one of their key demands. The president at the time, Sebastián Piñera (a conservative), did not accede to this, but greatly expanded student aid as a response to the students' expectations. However, the issue did not go away, and by the 2013 electoral campaign, free higher education became a central pledge 